\title{
SIMULTANEOUS EXPRESSION OF NEURONAL AND GLIAL PROPERTIES BY CHICK CILIARY GANGLION CELLS DURING DEVELOPMENT ${ }^{1}$
}

\author{
H. ROHRER ${ }^{2}$ AND I. SOMMER*
}

Department of Neurochemistry, Max-Planck-Institute for Psychiatry, 8033 Martinsried/Munich, and ${ }^{*}$ Department of Neurobiology, University of Heidelberg, 69 Heidelberg, Im Neuenheimer Feld 504, Federal Republic of Germany

Received November 8, 1982; Revised February 15, 1983; Accepted March 21, 1983

\begin{abstract}
Autoradiographic methods were used to show that non-neuronal cells from dissociated chick ciliary ganglia grown in cell culture for 1 day exhibit high affinity uptake for norepinephrine (NE) and/or specific receptors for nerve growth factor (NGF). Using immunofluorescence procedures, it was demonstrated that these cells reacted neither with the neuron-specific marker tetanus toxin nor with antibodies to the fibroblast marker fibronectin. The cells were, however, positive for 04 antigen, which is present on Schwann cells and oligodendrocytes and is recognized by a monoclonal antibody (Schachner, M., S. K. Kim, and R. Zehnle (1981) Dev. Biol. 83: 328-338). At all stages studied between embryonic day 6 (E6) and embryonic day 14 (E14), about $80 \%$ of the non-neuronal cells were positive for 04 antigen, the other non-neuronal cells being identified as fibroblasts or fibroblast-like cells by staining with antibodies to fibronectin. The proportion of cells with NGF receptors and cells with NE uptake decreased during development between E6 and E14. The percentage of 04-positive cells which have NGF receptors decreased from about $95 \%$ at E6 to about $35 \%$ at E14. The proportion of 04-positive cells with NE uptake decreased from about 57\% at E6 to about $15 \%$ at E14.

Thus, a considerable proportion of the non-neuronal cell population in embryonic ciliary ganglia displays neuronal properties. We suggest that those cells exhibiting biochemical properties of both differentiated glial cells and neurons are precursor cells which have the potential to develop either into glial cells or neurons.
\end{abstract}

Cells of the neural crest are the precursors of a variety of differentiated cell types, including pigment cells, skeletal and connective tissue cells, and neurons and glia of the peripheral nervous system. The pluripotent neural crest cells migrate during ontogenesis to their appropriate location and differentiate according to the influence of the environment (Yntema and Hammond, 1947; Weston, 1963; Le Douarin and Teillet, 1971, 1974; Cohen, 1972; Teillet and Le Douarin, 1974).

The differentiative pathway from a pluripotent stem cell to a mature neuron or supportive cell (satellite or Schwann cell) most probably includes stepwise restrictions in the differentiative potential of the neural crest

\footnotetext{
${ }^{1}$ We thank Hans Thoenen and Melitta Schachner for their support and helpful discussions. Additionally we would like to thank Karin Wiedenmann and Angelika Kiener for excellent technical assistance. Support from Gemeinnützige Hertie Stiftung is gratefully acknowledged.

${ }^{2}$ To whom correspondence should be addressed.
}

derivatives (Weston, 1981). This might also be reflected by the elimination of certain properties which are expressed initially on all cells but later are restricted to become the specific characteristic of differentiated cell types (De Vitry et al., 1980; Linser and Moscona, 1981). Whether a cell which has acquired the characteristics of a differentiated cell (e.g., cell type-specific enzymes, surface antigens) is then able to alter its phenotype has been the object of many studies. For example, it has been shown in vitro that adrenergic neurons, even at relatively advanced stages of their development, can still be influenced to acquire properties specific for cholinergic neurons (for review see Patterson, 1978). In vivo, the transplantation of ganglia of the peripheral nervous system in early embryos has also been used to probe the developmental potential of the ganglionic cells (for review see Le Douarin, 1980). These studies demonstrated that ganglionic cells are able to re-enter a migration pathway within the host embryo and acquire characteristics different from those of the cell types present in the ganglia 
at the time of implantation. For example, cells from transplanted cholinergic ciliary ganglia can develop into adrenergic neurons (Le Douarin et al., 1978). However, it is unclear whether the adrenergic neurons originated from ciliary neurons or from precursor cells still present in the ganglion at the time of implantation.

In the course of an in vitro analysis of the potential of ciliary ganglia cells to acquire adrenergic characteristics, we discovered that a considerable proportion of the morphologically distinguishable non-neuronal cells present in the ganglia, but not the neurons, have properties characteristic of adrenergic neurons: they have a high affinity uptake for norepinephrine (NE) as well as receptors for nerve growth factor (NGF). The aim of the present study was to characterize the cells with these properties using cell-specific markers and to analyze the expression of NGF receptors and norepinephrine uptake in chick ciliary non-neuronal cells during development.

\section{Materials and Methods}

\section{Preparation of cell cultures}

Ciliary ganglia were dissected from 6-, 10-, and 14day-old chick embryos (E6, E10, E14) according to the method of Helfand et al. (1976). Ganglia were cleaned of loose mesenchyme and nerve roots. They were incubated for $25 \mathrm{~min}$ at $37^{\circ} \mathrm{C}$ with $0.1 \%$ trypsin (Worthington) in $\mathrm{Ca}^{2+} / \mathrm{Mg}^{2+}$-free phosphate-buffered saline (PBS). In some cases ganglia from E14 embryos were incubated with a mixture of $0.4 \%$ trypsin and $0.2 \%$ collagenase (CLS, Worthington). After the incubation ganglia were washed twice with F14 medium (made from GIBCO F12 powder supplemented as described by Vogel et al., 1972) containing $10 \%(\mathrm{v} / \mathrm{v})$ horse serum (Flow) (F14/ HS). The ganglia were then dissociated by trituration with a siliconized Pasteur pipette. Dissociated cells were counted in a hemocytometer under phase contrast optics. The yield of neurons, identified by morphological criteria (large, phase-bright cells with smooth contour) was 9,600 $\pm 1,400(\mathrm{SD}, n=3)$ at $\mathrm{E} 6,8,000 \pm 600(\mathrm{SD}, n=3)$ at $\mathrm{E} 10$, and $3,200 \pm 300(\mathrm{SD}, n=6)$ at E14. The yield of neurons obtained by this procedure (Varon et al., 1979) is higher at $\mathrm{E} 6$ and $\mathrm{E} 10$, but not at E14, than the number of neurons per ciliary ganglion determined in histological sections (Landmesser and Pilar, 1974a, b; for discussion see Varon et al., 1979). The yield of non-neuronal cells (small, phase-dark cells with irregular contour) increased from $9,200 \pm 1,200(\mathrm{SD}, n=3)$ at $\mathrm{E} 6$ to $39,600 \pm 6,700$ (SD, $n=6)$ at E14.

The cell suspension was added at a cell density of 80,000 cells/dish (neurons and non-neuronal cells) to 35mm plastic tissue culture dishes which had been coated with collagen (type III, Sigma). In some experiments cells were cultured on a substrate consisting of polyornithine (Sigma, type I-B) coated with heart-conditioned medium (PORN/HCM) as originally described by Harper et al. (1982). Neurons were more firmly attached on the PORN/HCM substrate than on collagen, thus excluding the possible loss of neurons during repeated washing steps. The culture medium consisted of F14/HS supplemented with hen brain extract (200 $\mu \mathrm{g}$ of protein/ $\mathrm{ml})$.

\section{Preparation of hen brain extract}

A survival factor for ciliary ganglion neurons was prepared from hen brain. It is well established that ciliary neurons, like many other embryonic neurons, require the presence of a trophic factor to survive in culture (Helfand et al., 1976; Nishi and Berg, 1977, 1979; Varon et al., 1979). The brain extract used in this study maintains virtually all plated neurons from E6 to E14 ciliary ganglia up to a period of at least 6 days in culture. The activity of different fractions on neuronal survival was tested in the absence of non-neuronal cells as described previously for chick dorsal root neurons (Barde et al., 1982). The following preparation scheme was found to give a suitable fraction with activity promoting the survival of ciliary neurons. Frozen hen brains from adult animals (30 gm) were homogenized in $300 \mathrm{ml}$ of PBS containing $2 \mathrm{mM}$ phenylmethansulfonylfluoride using an Ultra-Turrax homogenizer. The homogenate was centrifuged for 20 $\min$ at $20,000 \times g$. The activity in the supernatant was precipitated by ammonium sulfate ( 40 to $80 \%$ ), and the pellet was dissolved in $0.1 \mathrm{M}$ acetate buffer, $\mathrm{pH} 5$, and kept for $1 \mathrm{hr}$ at $0^{\circ} \mathrm{C}$. The precipitate formed was removed by centrifugation; the supernatant was neutralized and then dialyzed against $50 \mathrm{~mm}$ Tris- $\mathrm{HCl}, \mathrm{pH} 7.5,0.1 \mathrm{M}$ $\mathrm{NaCl}, 0.5 \mathrm{~mm}$ EDTA, 20 KIU (Kallikrein inhibitor units) $/ \mathrm{ml}$ of aprotinin (Sigma). The dialysate was applied to a Sephadex G-100 $(3 \times 100 \mathrm{~cm})$ column equilibrated with the same buffer. The fractions of the void volume were combined, dialyzed against distilled $\mathrm{H}_{2} \mathrm{O}$, and lyophilized. About $60 \mathrm{mg}$ of lyophilized material were obtained from $30 \mathrm{gm}$ of hen brain. This fraction is referred to as hen brain extract (HBE). It is stable at $4^{\circ} \mathrm{C}$ for at least 4 months (the longest period tested). 'The concentration of HBE necessary to achieve maximal survival of ciliary neurons was 100 to $200 \mu \mathrm{g} / \mathrm{ml}$ on either collagen or HCM/PORN. The preparation scheme described did not lead to an increase of the specific activity (tested after 2 days) of the extract when compared to the initial homogenate in PBS but removed activities interfering with the long-term survival of neurons at saturating concentrations of hen brain extract. In cultures maintained for 6 days, neurons were connected by a dense network of fibers on a nearly confluent monolayer of non-neuronal cells. The number of neurons decreased by about $10 \%$ after 6 days in culture.

\section{$\left[{ }^{3} H\right]$ Noradrenaline uptake}

Cultures. Cultures were washed twice with a modified Krebs-Ringer-Henseleit buffer (Greene and Rein, 1977) supplemented with $0.1 \%$ bovine serum albumin (BSA) (KRH/A) incubated with $0.5 \mu \mathrm{M}$ levo-ring-2,5,6- $\left[{ }^{3} \mathrm{H}\right]$ norepinephrine (New England Nuclear) (37 to $47 \mathrm{Ci} / \mathrm{mmol}$ ) for $1 \mathrm{hr}$ at $37^{\circ} \mathrm{C}$ in the presence of $1 \mathrm{~mm}$ ascorbate. In control incubations, desipramine (DMI) (Ciba-Geigy) was added at a concentration of $0.5 \mu \mathrm{M}$. In sodium-free control incubations, $\mathrm{NaCl}$ was replaced by $\mathrm{LiCl}$ in the Krebs-Ringer-Henseleit buffer. After the incubation, cultures were washed three times with $\mathrm{KRH} / \mathrm{A}$ supplemented with ascorbate and $24 \mathrm{mM}$ DL-norepinephrine and fixed with $4 \%$ formaldehyde plus $2.5 \%$ glutaraldehyde in PBS for $20 \mathrm{~min}$ at room temperature. The 
cultures were then rinsed three times with PBS and three times with $\mathrm{H}_{2} \mathrm{O}$ and processed for autoradiography as described previously (Rohrer and Barde, 1982). In some experiments cultures were pretreated with pargyline (Sigma) $(30 \mu \mathrm{M})$ in F14/HS supplemented with HBE for $30 \mathrm{~min}$ at $37^{\circ} \mathrm{C}$, followed by a washout period of $1 \mathrm{hr}$ at $37^{\circ} \mathrm{C}$ with a change of medium every $15 \mathrm{~min}$. After the washout $\left[{ }^{3} \mathrm{H}\right] \mathrm{NE}$ uptake was assayed as described above.

Ganglia. Ciliary ganglia were dissected from 6-day-old embryos and collected in F14 supplemented with $0.1 \%$ BSA. Ganglia were then incubated with $0.5 \mu \mathrm{M}\left[{ }^{3} \mathrm{H}\right] \mathrm{NE}$ in F14 supplemented with $0.1 \%$ BSA and $1 \mathrm{mM}$ ascorbate at $37^{\circ} \mathrm{C}$ in a $4 \% \mathrm{CO}_{2} / 96 \%$ air atmosphere. Control incubations contained in addition $0.5 \mu \mathrm{M}$ DMI. After $30 \mathrm{~min}$, $1 \mathrm{hr}$, and $2 \mathrm{hr}$, three ganglia were removed, washed four times in $1 \mathrm{ml}$ of $\mathrm{F} 14$ (within $5 \mathrm{~min}$ ), and homogenized separately in $90 \mu \mathrm{l}$ of $0.1 \mathrm{M}$ perchloric acid using a motordriven Teflon-glass homogenizer. The homogenates were added to $10 \mathrm{ml}$ of scintillation fluid (Aqualuma, Baker) and counted in a Berthold liquid scintillation spectrometer at 30 to $35 \%$ efficiency.

\section{Determination of NGF receptors}

NGF was isolated and iodinated as described previously (Rohrer and Barde, 1982). Cultures were washed twice with KRH supplemented with $0.5 \%$ BSA, incubated with $5 \mathrm{ng} / \mathrm{ml}$ of $\left[{ }^{125} \mathrm{I}\right] \mathrm{NGF}$ (180 to $250,000 \mathrm{cpm} /$ ng) for $1 \mathrm{hr}$ at $37^{\circ} \mathrm{C}$ in $\mathrm{KRH} / 0.5 \% \mathrm{BSA}$, washed three times, fixed, and processed for autoradiography as described previously (Rohrer and Barde, 1982). Control incubations contained $10 \mu \mathrm{g} / \mathrm{ml}$ of unlabeled NGF or 50 $\mu \mathrm{g} / \mathrm{ml}$ of cytochrome $c$.

\section{Immunocytological procedures}

Antigens 04 and 01 were demonstrated in cultures of ciliary ganglion cells by indirect immunofluorescence as described by Sommer and Schachner (1981). For combined fluorescence and autoradiography analysis, 04 antibody was added at $37^{\circ} \mathrm{C}$ during the last $20 \mathrm{~min}$ of the $\left[{ }^{3} \mathrm{H}\right] \mathrm{NE}$ or $\left.{ }^{125} \mathrm{I}\right] \mathrm{NGF}$ uptake period. After washing and fixation with $4 \%$ paraformaldehyde plus $2.5 \%$ glutaraldehyde in PBS, the 04-positive cells were identified with fluorescein isothiocyanate (FITC)-labeled goat antimouse antiserum (Miles) (GAM-FITC). Randomly selected areas of the culture dish were photographed; the cultures were washed, dried, and covered with photographic emulsion. After an exposure time of 7 or 21 days (NE uptake or NGF binding), the emulsion was developed and labeled cells were identified by the silver grains on top of the cells. Fibroblast-like cells were identified by indirect immunofluorescence using goat anti-human fibronectin $\left(\left(\mathrm{Fab}^{\prime}\right)_{2}\right.$ fragment, Cappel) and FITC-labeled rabbit anti-goat (GIBCO) globulin (RAG-FITC). For the simultaneous demonstration of fibronectin and 04 antigen (Fig. 3), paraformaldehyde-fixed cultures were treated sequentially with anti-fibronectin (1:20), RAGFITC (1:20), and then with anti-04 (1:20) followed by rhodamine isothiocyanate (TRITC)-labeled rabbit antimouse (Nordic) (1:100). Staining with tetanus toxin was performed using the indirect immunofluorescence method of Mirsky et al. (1978). The tetanus toxin was a gift from Dr. B. Bizzini, Institut Pasteur, Paris; human anti-tetanus toxin was a gift from Dr. Johannsen, Behring-Werke, Marburg; and FITC-conjugated goat antihuman $\gamma$-globulin was purchased from Behring-Werke, Marburg. Monoclonal antibodies against $210 \mathrm{~K}$ neurofilament protein (RT97) were a gift from Dr. J. Wood, Wellcome Research Laboratories, Beckenham.

\section{Results}

\section{Characterization of different cell types present in cultures of dissociated ciliary ganglia}

Both neurons and non-neuronal cells survived when cultured on a collagen substrate in F14 medium supplemented with horse serum and an extract of hen brain. Throughout this study, cultures maintained in vitro for 1 day were used, at which time between 80 and $90 \%$ of the cells plated were still alive. By morphological criteria, neurons with their round, phase-bright cell bodies and phase-dark, flattened non-neuronal cells could clearly be distinguished (Fig. 1). Neurons from E6 and E10 embryos produced long processes during 1 day in culture, whereas neurons from E14 embryos displayed only short or no processes (Fig. 1). In addition to morphological criteria, cell-specific markers were used to identify the different cell types present in our cultures: as neuronal markers, the binding of tetanus toxin and the presence of a neurofilament protein were used (Dimpfel et al., 1975; Mirsky et al., 1978; Yen and Fields, 1981). As markers for glial cells and/or their precursors, we used the antigens 04 and 01 defined by monoclonal antibodies (Schachner et al., 1981; Sommer and Schachner, 1981). Cells with typical neuronal morphology bound significant amounts of tetanus toxin and contained detectable levels of neurofilament protein, as measured by indirect immunofluorescence. Cells with non-neuronal morphology were shown to be negative for these markers (data not shown).

The non-neuronal cell population of chick ciliary ganglia consists of about $80 \%$ of cells which are positive for 04 at all ages between E6 and E14 (Fig. 2, $a$ and $d$ ). Antigen 01 is not detectable at E6 and E10 (Fig. 2, $b$ and e) but at E14 between $5 \%$ and $15 \%$ of the non-neuronal cells are positive for 01 (Fig. 2, $a$ and $f$ ). These cells are more elongated and appear morphologically to be more mature than 01-negative cells (Fig. 2, $a$ and $f$ ).

The remaining $20 \%$ of the non-neuronal cell population were identified as fibroblasts or fibroblast-like cells by indirect immunofluorescence using antibodies against fibronectin (Fig. 3). Double label experiments with anti04 and anti-fibronectin antibodies showed that the populations of 04-positive cells and fibronectin-positive cells were distinct and separate; no cells with both antigens were present (Fig. 3).

Cells with neuronal morphology and which expressed tetanus toxin binding sites and neurofilament protein were negative for 04,01 (Fig. 2), and fibronectin. We conclude from these experiments that the 04 antigen can be regarded as an early marker for fibronectin-negative non-neuronal cells of the ciliary ganglion. 

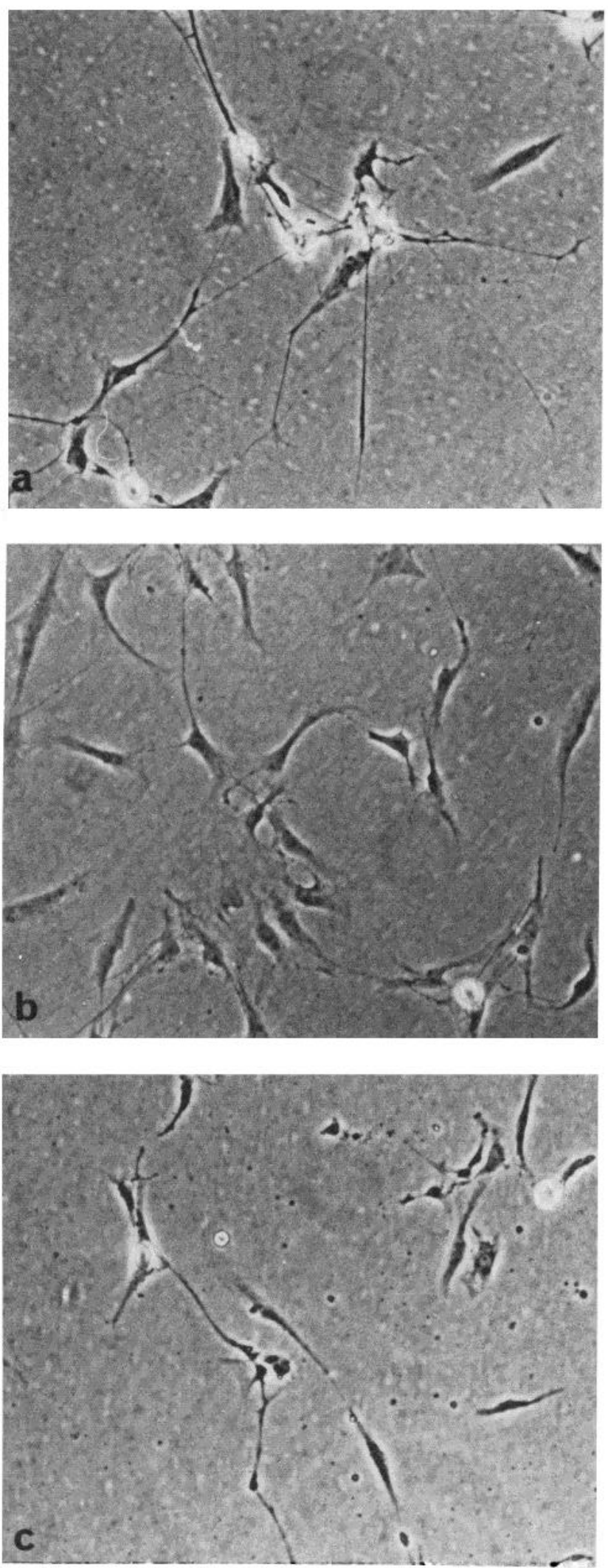

Figure 1. Morphology of neurons and non-neuronal cells in ciliary ganglia cultures. Cells from ciliary ganglia prepared from E6 $(a)$, E10 $(b)$, and E14 $(c)$ chick embryos and grown for 1 day in the presence of hen brain extract $(0.2 \mathrm{mg} / \mathrm{ml})$. Magnification $\times 300$.

\section{High affinity uptake of norepinephrine in the chick} ciliary ganglion

Cultures of dissociated ciliary ganglia. Non-neuronal cells from chick ciliary ganglia were shown to have a high affinity uptake system for $\left[{ }^{3} \mathrm{H}\right] \mathrm{NE}(0.5 \mu \mathrm{M})$ by autoradiography (Fig. 4, $a$ and $e$ ). Labeling of cells was completely inhibited by $0.5 \mu \mathrm{M}$ DMI (Fig. $4, b$ and $f$ ), a specific inhibitor of the high affinity NE uptake (Glow- $^{-}$ insky and Axelrod, 1964). The uptake of norepinephrine was also inhibited when $\mathrm{NaCl}$ in the Krebs-RingerHenseleit buffer was replaced by $\mathrm{LiCl}$ (data not shown),

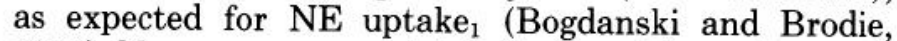
1969). Neurons were not labeled using either collagen or PORN/HCM as a substrate. NE uptake-positive cells were detected in cultures obtained from ciliary ganglia of all ages studied (E5 to E14). This property is present not only in non-neuronal cells from ciliary ganglia, but also in cultured non-neuronal cells from chick sympathetic and dorsal root ganglia $(H$. Rohrer, unpublished observations).

Intact ciliary ganglia. In order to exclude the possibility that the ability of cells to take up NE was artificially induced by the dissociation and cultivation procedures, freshly dissected, intact ganglia from 6-day-old embryos were incubated with $\left[{ }^{3} \mathrm{H}\right] \mathrm{NE}(0.5 \mu \mathrm{M}, 48.5 \mathrm{Ci} / \mathrm{mmol})$ for periods of up to $3 \mathrm{hr}$. A DMI-sensitive uptake of NE was observed which reached a plateau after about $1.5 \mathrm{hr}$ of incubation. At that time $1700 \pm 220 \mathrm{cpm}$ (mean $\pm \mathrm{SD}$ of triplicate determinations) had been taken up per ganglion in the absence of DMI. In the presence of $0.5 \mu \mathrm{M}$ DMI, the uptake was decreased to $290 \pm 40 \mathrm{cpm} / \mathrm{gan}-$ glion.

\section{NGF receptors on cultured chick ciliary ganglion cells}

Non-neuronal cells also had receptors for NGF, reflected by the binding and possible internalization of ${ }^{125} \mathrm{I}$ labeled NGF (Fig. 4, $c$ and $g$ ). The specificity of the binding was established by demonstrating that ciliary neurons and fibroblasts were not labeled, and that the $\left[{ }^{125} \mathrm{I}\right] \mathrm{NGF}$ labeling of non-neuronal cells was abolished by a large excess $(10 \mu \mathrm{g} / \mathrm{ml})$ of unlabeled NGF (Fig. $4, d$ and $h$ ). Moreover, in the presence of $50 \mu \mathrm{g} / \mathrm{ml}$ of cytochrome $c$, the labeling of the non-neuronal cells with $\left[{ }^{125} \mathrm{I}\right] \mathrm{NGF}$ was not reduced.

\section{Characterization of cells with $N G F$ receptors or NE uptake using antigenic markers}

Double label experiments identifying 04 antigen by immunofluorescence and NE uptake and NGF receptors with autoradiography established that all cells with DMIsensitive NE uptake and all cells with specific NGF receptors were positive for 04 (Fig. 5). A total of about 300 cells positive for NE uptake and about 400 cells with NGF receptors have been analyzed at three embryonic ages, E6, E10 and E14.

\section{Determination of the proportion of cells with NE uptake and NGF receptors at different developmental ages}

The proportion of 04-positive cells with NE uptake or NGF receptors decreased during development (Table I). The proportion of cells with NGF receptors was considerably higher than the proportion of cells with NE up- 

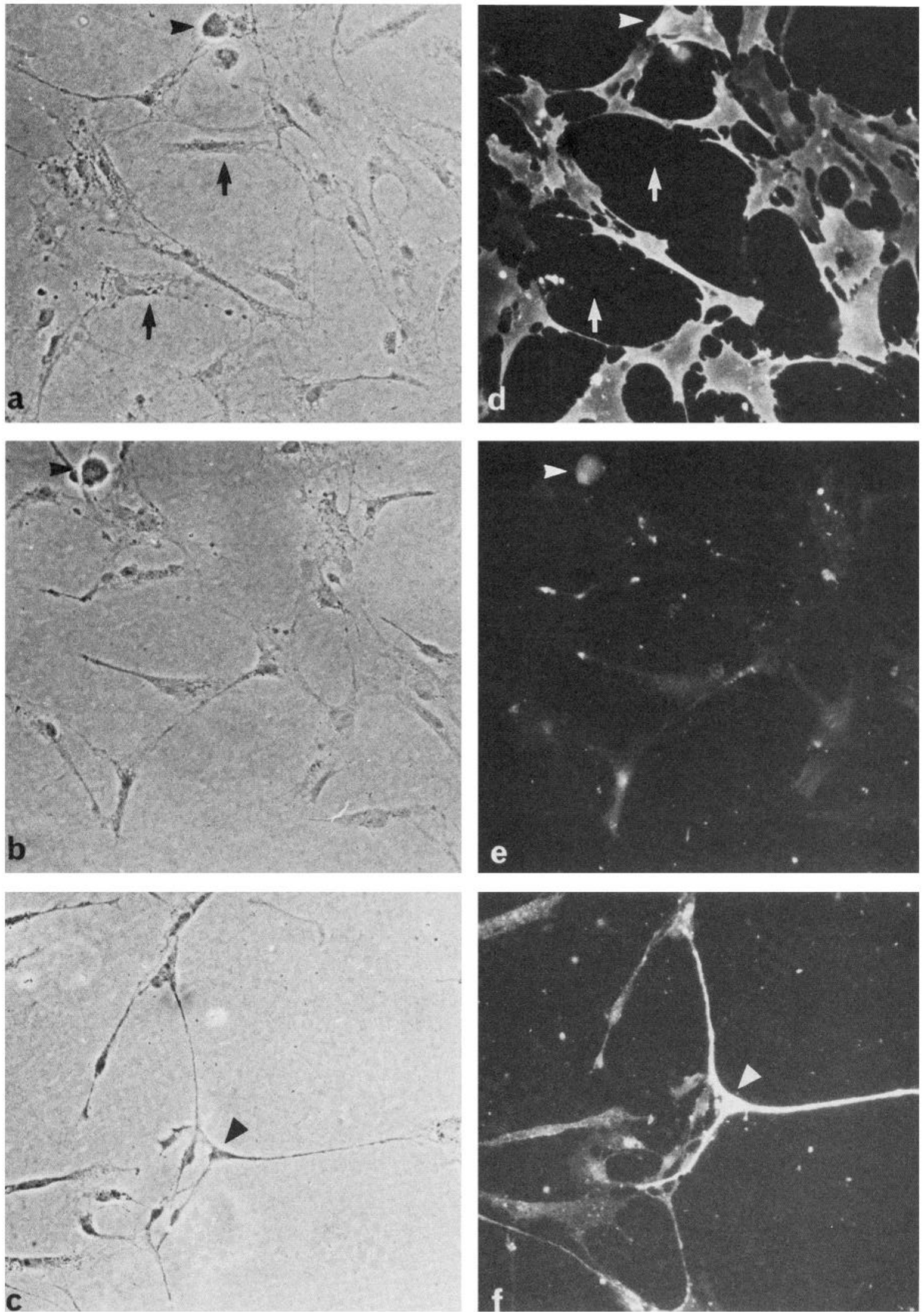

Figure 2. Immunolabeling of 04 and 01 antigen in cultures of ciliary ganglia from 10- and 14-day-old chick embryos. Antigens $04(d)$ and $01(e$ and $f)$ were tested by indirect immunofluorescence after 1 day in culture. $a, b, d$, and $e$, E10 ciliary ganglion cells; $c$ and $f$, E14 ciliary ganglion cells. Arrows point to 04-negative cells ( $a$ and $d$ ). Note: At E10 most of the non-neuronal cells are 04 positive but 01 negative. At E14 a small percentage of the non-neuronal cells are 01 positive ( $c$ and $f$, arrowhead) ( 5 to $10 \%)$. In contrast to the epithelial morphology of non-neuronal cells at E10, at E14 most 04-positive cells show a more mature spindle-shaped morphology. Neurons (arrowheads in $a, b, d$, and $e$ ) are negative for both 04 and 01 antigen. Magnification $\times$ 220 . 

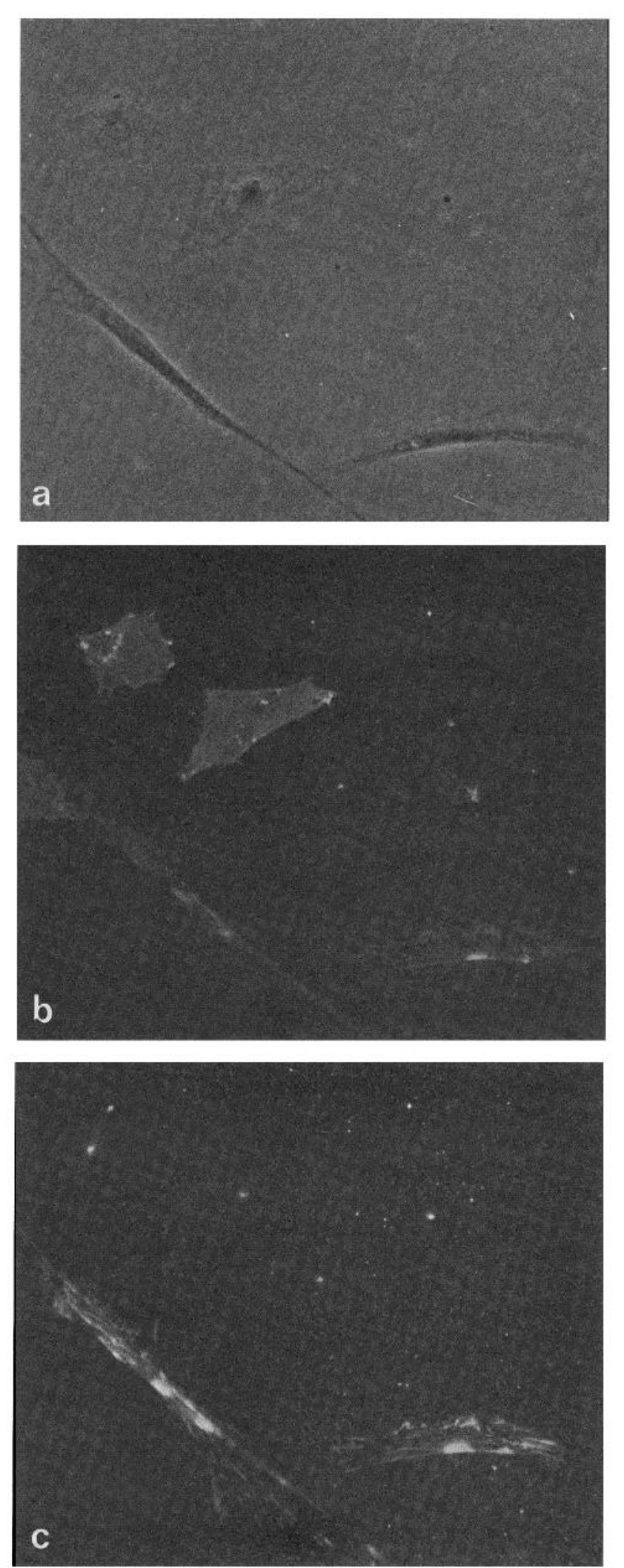

Figure 3. Double immunolabeling for fibronectin and 04 antigen in cultures of ciliary ganglia from 10-day-old chick embryos. $a$, Phase contrast; $b$, antigen 04 ; $c$, fibronectin. Magnification $\times 300$. take. All NE ${ }^{+}$cells were NGF receptor positive, but not all cells with NGF receptors showed NE uptake. This was established in three independent experiments at two embryonic ages: when both NE and NGF were present during the labeling period the proportion of labeled cells was not larger than with NGF alone. The decreased proportion of 04-positive cells taking up NE at E14 was not due to an increased degradation of NE by monoamine oxidase: pretreatment of E14 cultures with pargyline (30 $\mu \mathrm{M})$, a specific inhibitor of monoamine oxidase, did not influence the proportion of non-neuronal cells taking up NE. Between E6 and E14 the total number of cells (per ganglion) with NE uptake increased by $13 \%$ and the total number of cells with NGF receptors by $63 \%$.

\section{Discussion}

This investigation demonstrates that some non-neuronal cells of the chick ciliary ganglion have a high affinity uptake for NE and receptors for NGF. Moreover all cells with NE uptake and/or NGF receptors are positive for the glial (oligodendroglial and Schwann cell) marker 04 but are negative for fibronectin, a marker for fibroblast or fibroblast-like cells. The fact that the proportion of 04-positive cells with NE uptake or NGF receptors decreases during development suggests that these cells are pluripotent precursor cells which may have the potential to differentiate into both neurons and glial cells.

Although a low affinity uptake system for norepinephrine (uptake $_{2}$ has been described for non-neuronal cells (Iversen 1965; Gillespie, 1973) the DMI-sensitive, sodium-dependent noradrenaline uptake is $_{1}$ characteristic of neurons (Iversen, 1973). The high affinity norepinephrine uptake ${ }_{1}$ appears very early during the differentiation of neural crest cells into sympathicoblasts (Rothman et al., 1978) and remains preserved under conditions when rat sympathetic neurons have acquired cholinergic properties and virtually have lost their ability to synthesize catecholamines (Reichardt and Patterson, 1977; Wakshull et al., 1978). By two criteria, the uptake of noradrenaline into glial cells shown here was classified as the neuronal-type NE uptake ${ }_{1}$ : (1) The uptake was blocked by DMI. (2) The uptake was $\mathrm{Na}^{+}$dependent. It was also shown that the ability of cells to take up norepinephrine by a DMI-sensitive mechanism is present in intact ganglia. In addition to NE uptake the ciliary non-neuronal cells were shown in the present study to express receptors for NGF. NGF acts on sensory and sympathetic neurons of the peripheral nervous system during development and also in the adult stage (Thoenen and Barde, 1980). So far no function of NGF in nonneuronal cells has been detected, although receptors for NGF have been demonstrated not only on responsive neurons but also on non-neuronal cells from embryonic chick dorsal root ganglia and on melanoma cells (Sherwin et al., 1979; Sutter et al., 1979a, b; Carbonetto and Stach, 1982; Zimmermann and Sutter, 1982). The NGF receptor on non-neuronal cells has a dissociation constant of $2 \times$ $10^{-9} \mathrm{M}$, whereas on neurons two kinds of NGF receptors have been found with dissociation constants of $2 \times 10^{-11}$ $\mathbf{M}$ and $2 \times 10^{-9}$ M (Sutter et al., 1979a, b; Carbonetto and Stach, 1982). Chick ciliary neurons have no NGF 

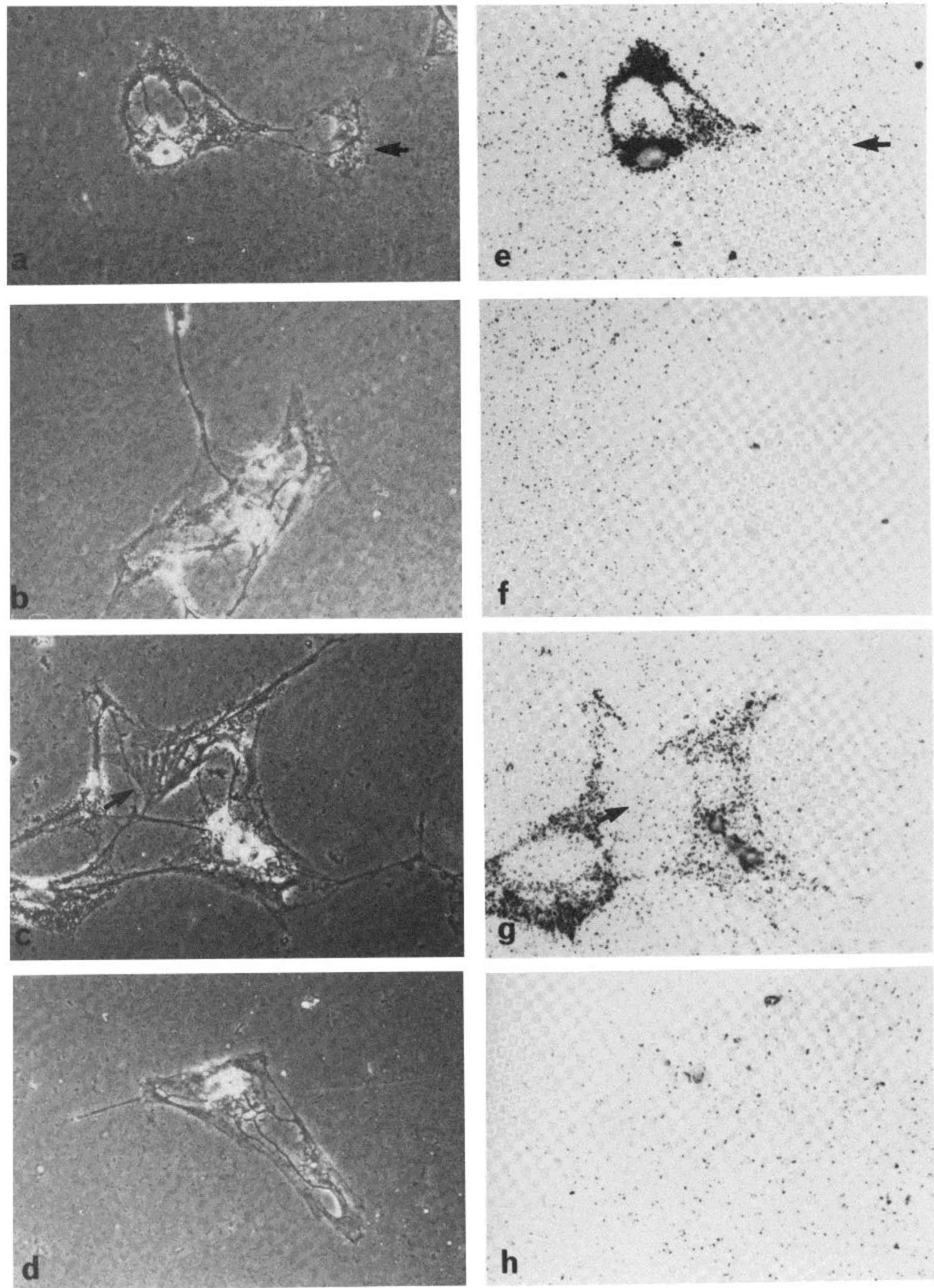

Figure 4. Autoradiographic demonstration of NE uptake and NGF receptors in culture. E10 ciliary ganglion cells were cultured for 1 day. The cultures were incubated at $37^{\circ} \mathrm{C}$ with $\left[{ }^{3} \mathrm{H}\right]$ norepinephrine $(0.5 \mu \mathrm{M})$ either alone $(a$ and $e)$ or in the presence of desmethylimipramine $(0.5 \mu \mathrm{M})(b$ and $f)$ and with [ $\left.{ }^{125} \mathrm{I}\right] \mathrm{NGF}(5 \mathrm{ng} / \mathrm{ml})$ either alone $(c$ and $g)$ or with an excess of unlabeled NGF $(d$ and $h$ ). After the incubation the cultures were washed, fixed, and processed for autoradiography ( $a$ to $d$, phase contrast; $e$ to $h$, bright field). Note that only some non-neuronal cells are labeled. Arrows point to unlabeled cells. Magnification $\times 300$. 

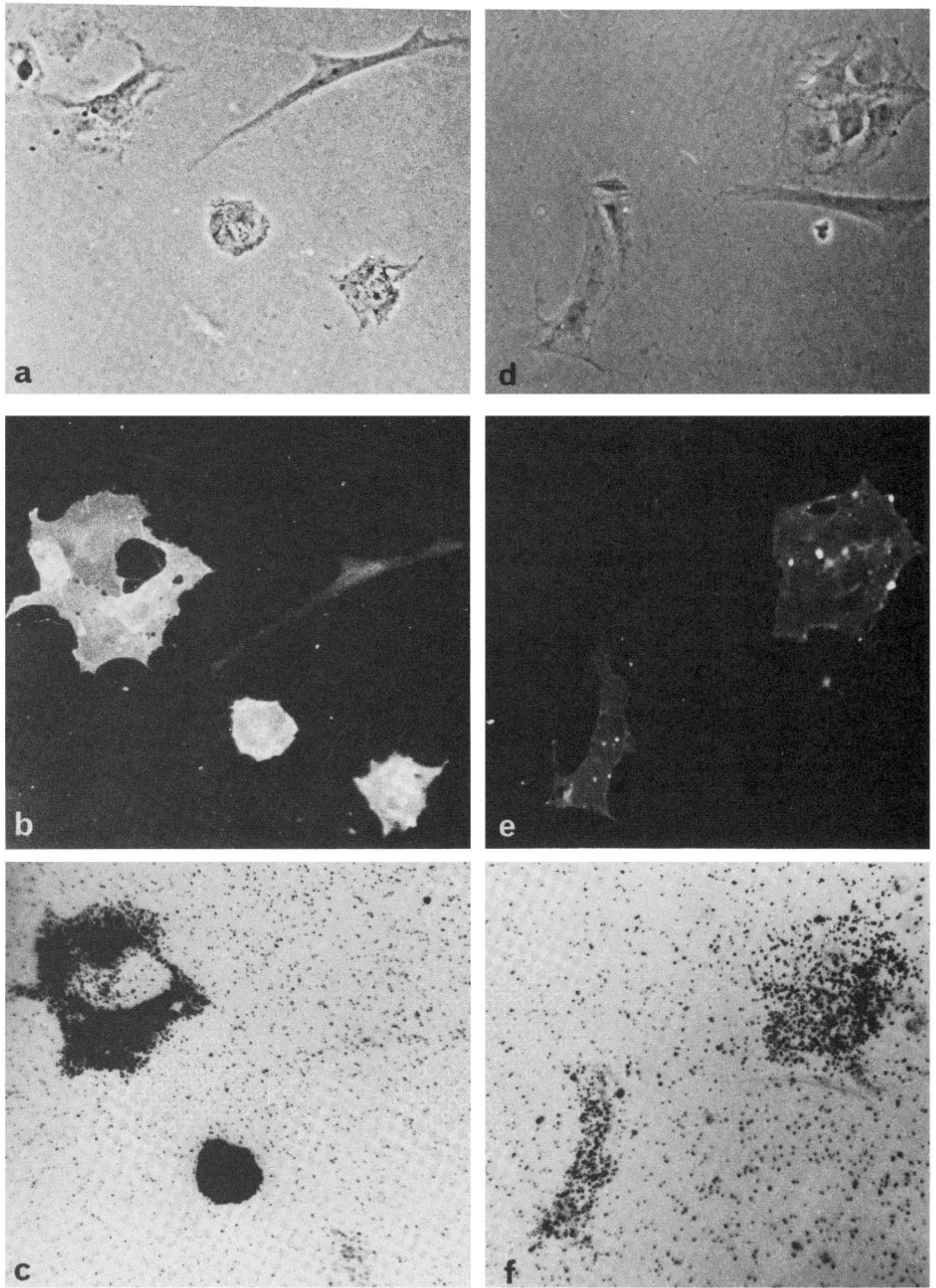

Figure 5. Combined autoradiography for internalized $\left[{ }^{3} \mathrm{H}\right] \mathrm{NE}$ or $\left[{ }^{125} \mathrm{I}\right] \mathrm{NGF}$ and immunofluorescence for 04 antigen. E10 ciliary ganglion cells were incubated at $37^{\circ} \mathrm{C}$ simultaneously with $\left[{ }^{3} \mathrm{H}\right]$ norepinephrine or $\left[{ }^{125} \mathrm{I}\right] \mathrm{NGF}$ and monoclonal antibodies against 04 antigen. After the incubation, the cultures were washed, fixed, and processed for immunofluorescence and autoradiography. $a$ and $d$, Phase contrast micrograph; $b$ and $e$, indirect immunofluorescence for 04 antigen; $c$, autoradiography of $\left[{ }^{3} \mathrm{H}\right] \mathrm{NE} ; f$, autoradiography of $\left[{ }^{125} \mathrm{I}\right] \mathrm{NGF}$. Magnification $\times 300$. 
TABLE 1

Percentage of 04 antigen-positive cells with NGF receptors or NE uptake in cultures of 6-and 14-day-old ciliary ganglia after 1 day in vitro

The percentage of non-neuronal cells positive for NE uptake or NGF receptors was determined after autoradiography as described previously (Rohrer and Barde, 1982). In sister cultures the percentage of $04^{+}$cells was determined by indirect immunofluorescence. The results are expressed as percentage of $04^{+}$cells with NE uptake or NGF receptors $\pm \mathrm{SEM}$ of three to five determinations.

\begin{tabular}{ccc}
\hline \multirow{2}{*}{ Embryonic Age } & \multicolumn{2}{c}{ Percentage 04 ${ }^{+}$Cells with } \\
\cline { 2 - 3 } & NE uptake & NGF receptors \\
\hline E6 & $57 \pm 11$ & $95 \pm 5$ \\
E14 & $15 \pm 5^{a}$ & $36 \pm 13^{a}$ \\
\hline
\end{tabular}

${ }^{a}$ Significantly $(p<0.005)$ different from E6 cultures.

receptors (Kohrer and Barde, 1982, and the present study). NGF receptors have also been observed on nonneuronal cells of sympathetic ganglia (H. Rohrer, unpublished data). The fact that non-neuronal cells of the ciliary ganglion also have NGF receptors indicates that the presence of NGF receptors seems to be a general property of non-neuronal cells in ganglia of the peripheral nervous system irrespective of the presence of NGF receptors on the neurons present in the ganglion.

The simultaneous demonstration of glial antigens in cells with NE uptake or NGF receptors is important for the interpretation of this observation. By morphological criteria these cells were classified as non-neuronal cells (Figs. 1 and 4). This classification was confirmed by showing that the neuron-specific markers tetanus toxin receptor and a neurofilament protein were absent in all of the flat non-neuronal cells as judged by indirect immunofluorescence. The cells with NE uptake and NGF receptors werc recognized by a monoclonal antibody directed against an antigen shown previously to be specifically present on cerebellar oligodendrocytes and on part of the fibronectin-negative non-neuronal cell population of cultured dorsal root ganglia from newborn mice (Schachner et al., 1981; Sommer and Schachner, 1981). In cultures of ciliary ganglia the 04 antigen was detected only on flat non-neuronal cells. We could thus show that the non-neuronal cell populaton of ciliary ganglia consists of two distinct subpopulations, the 04-positive and fibronectin-positive cells. Furthermore, all NE uptakepositive or NGF receptor-positive cells are included in the 04-positive subpopulation. If the presence of both glial and neuronal characteristics on the same cells means that these cells are pluripotent and might have the potential to differentiate into neurons and glial cells, then the 04-positive cells which have neither NGF receptors nor NE uptake can be considered to be glial cells or precursors of glial cells.

The 04 antigen belongs to a group of antigens defined by monoclonal antibodies termed 01, 02, 03, 04 (Sommer et al., 1981) which appear at different times during development of mouse cerebellar oligodendrocytes (Schachner et al., 1981). 04 is detectable on both immature and mature oligodendrocytes, whereas 01 is detectable only on more mature oligodendrocytes (Sommer and Schachner, 1982) which are also positive for galactocerebroside. A similar time course of appearance of antigens is displayed by the fibronectin-negative non-neuronal cells of the chick ciliary ganglion. At E6 and E10, only 04-positive cells but no 01-positive cells could be detected, whereas at E14 about 5\% to $10 \%$ of the nonneuronal cell population was positive for the 01 antigen. 01-positive cells were always spindle shaped in contrast to the more epitheloid, more simple morphology of 04positive cells. In contrast to the analysis of cultured mouse dorsal root ganglion (Schachner et al., 1981), no 04-positive neurons were detected in cultures of dissociated ciliary ganglion at E6, E10, and E14 (Fig. 2).

We then investigated the expression of NE uptake and NGF receptors by 04-positive non-neuronal cells at different developmental stages. When cultures obtained from E6 or E14 chick ciliary ganglia were analyzed, an increased absolute number of 04-positive cells with $\mathrm{NE}$ uptake or with NGF receptors per ganglion was observed, but, due to the even larger increase in the absolute number of 04-positive cells, there was a reduction in the proportion of 04-positive cells with these properties. Since the plating efficiency ranged between 80 and $90 \%$ both at E6 and at E14, the decrease in the proportion of E14 non-neuronal cells with NE uptake cannot be explained by assuming that the cells with that property are selectively dying in culture at E14. Another possibility would be that these cells would be selectively lost during the dissociation of ganglia from older embryos. Two observations argue against this possibility: (1) The yield of neurons also from E14 ganglia is as high as to be expected from the number of neurons per ganglion as determined by Landmesser and Pilar (1974a, b). (2) The proportion of non-neuronal cells with NE uptake and/or NGF receptors was not increased when ganglia from E10 or E14 embryos were dissociated after an incubation with a mixture of collagenase and trypsin instead of trypsin alone, which allows the dissociation of the older ganglia with less mechanical effort. Thus, we assume that the reduced proportion of cells with NE uptake and/or NGF receptors in culture reflects a decrease in the proportion of cells with these properties in vivo. The increase in the number of multiproperty cells per ganglion might be expected if they belong to the glial cell lineage and are generated as long as glial cells are born. Cells with the ability to become adrenergic neurons have been demonstrated in the quail ciliary ganglion up to E9 (Le Douarin, 1980).

Non-neuronal cells of chick spinal ganglia are developmentally pluripotent up to embryonic day 6 and can be induced by environmental cues to become melanocytes (Nichols and Weston, 1977; Nichols et al., 1977). Even later during development of the chick dorsal root ganglia, cells with the morphology of non-neuronal cells have been shown to have the potential to differentiate into neurons under certain conditions in vitro (Chalazonitis and Fischbach, 1980). Recently it has been observed that the non-neuronal cell population of quail nodose ganglia can differentiate into adrenergic neurons when transplanted into early chick embryos (Ayer-Le Lievre and Le Douarin, 1982). In normal development these differentiation pathways might be blocked by the interaction with neurons (Nichols et al., 1977; Ayer-Le Lievre and Le Douarin, 1982). In the central nervous system cells 
have been described which express both glial cell and neuron-specific proteins (S-100 and 14-3-2, respectively) and which were presumed to be stem cells able to differentiate either into neurons or glial cells (de Vitry et al., 1980). Thus, several lines of evidence indicate that pluripotent cells exist in the developing nervous system. In the case of the chick peripheral ganglia, such cells can be influenced by the environment to differentiate into melanocytes, neurons, or glial cells. We suggest that the population of non-neuronal cells of the ciliary ganglion with NE uptake and NGF receptors might represent such a pluripotent cell population.

\section{References}

Ayer-Le Lievre, C. S., and N. M. Le Douarin (1982) The early development of cranial sensory ganglia and the potentialities of their component cells studied in quail-chick chimeras. Dev. Biol. 94: 291-310.

Barde, Y. A., D. Edgar, and H. Thoenen (1982) Purification of a new neurotrophic factor from mammalian brain. EMBO J. 1: 549-553.

Bogdanski, D. F., and B. B. Brodie (1969) The effects of inorganic ions on the storage and uptake of ${ }^{3} \mathrm{H}$-norepinephrine by rat heart slices. J. Pharmacol. Exp. Ther. 165: 181189.

Carbonetto, S., and R. W. Stach (1982) Localization of nerve growth factor bound to neurons growing nerve fibers in culture. Dev. Brain Res. 3: 463-473.

Chalazonitis, A., and G. D. Fischbach (1980) Elevated potassium induces morphological differentiation of DRG neurons in dissociated cell culture. Dev. Biol. 78: 173-183.

Cohen, A. M. (1972) Factors directing the expression of sympathetic nerve traits in cells of neural crest origin. J. Exp. Zool. 179: 167-182.

de Vitry, F., R. Picart, C. Jacque, L. Legault, P. Duponey, and A. Tixier-Vidal (1980) Presumptive common precursor for neuronal and glial cell lineages in mouse hypothalamus. Proc. Natl. Acad. Sci. U. S. A. 77: 4165-4169.

Dimpfel, W., J. H. Neale, and E. Habermann (1975) ${ }^{125}$ I-labelled tetanus toxin as a neuronal marker on tissue cultures derived from embryonic CNS. Naunyn-Schmiedeberg's Arch. Exp. Pathol. Pharmacol. 290: 329-333.

Gillespie, J. S. (1973) Uptake of noradrenaline by smooth muscle. Br. Med. Bull. 29: 136-141.

Glowinski, J., and J. Axelrod (1964) Inhibition of uptake of tritiated noradrenaline in the intact rat brain by imipramine and structurally related compounds. Nature (Lond.) 204: 1318-1319.

Greene, L. A., and G. Rein (1977) Release, storage and uptake of catecholamines by a clonal line of nerve growth factor (NGF) responsive pheochromocytoma cells. Brain Res. 129: 247-263.

Harper, G. P., Y. A. Barde, D. Edgar, D. Ganten, F. Hefti, R. Heumann, K. W. Naujoks, H. Rohrer, J. E. Turner, and H. Thoenen (1983) Biological and immunological properties of the nerve growth factor from bovine seminal plasma: Comparison with the properties of mouse nerve growth factor. Neuroscience 8: 375-387.

Helfand, S. L., G. A. Smith, and N. K. Wessels (1976) Survival and development in culture of dissociated parasympathetic neurons from ciliary ganglia. Dev. Biol. 50: 541-547.

Iversen, L. L. (1965) The uptake of catecholamines at high perfusion concentrations in the rat isolated heart: A novel catecholamine uptake process. Br. J. Pharmacol. 25: 18-33.

Iversen, L. L. (1973) Catecholamine uptake processes. Br. Med. Bull. 29: 130-135.

Landmesser, L., and G. Pilar (1974a) Synapse formation during embryogenesis on ganglion cells lacking a periphery. J. Physiol. (Lond.) 241: 715-735.

Landmesser, L., and G. Pilar (1974b) Synaptic transmission and cell death during normal ganglionic development. J. Physiol. (Lond.) 241: 737-749.

Le Douarin, N. M. (1980) The ontogeny of the neural crest in avian embryo chimeras. Nature 286: 663-669.

Le Douarin, N. M., and M. A. Teillet (1971) Localisation par le méthode des greffes interspécifiques du territoire neural dont dérivent les cellulles adrenales surrénaliennes chez l'embryon d'Oiseau. C.R. Acad. Sci. O 272: 481-484.

Le Douarin, N. M., and M. A. Teillet (1974) Experimental analysis of the migration and differentiation of neuroblasts of the autonomic nervous system and of neurectodermal mesenchymal derivatives, using a biological cell marking technique. Dev. Biol. 41: 162-184.

Le Douarin, N. M., M. A. Teillet, C. Ziller, and I. Smith (1978) Adrenergic differentiation of cells of the cholinergic ciliary and Remak ganglia in avian embryo after in vivo transplantation. Proc. Natl. Acad. Sci. U. S. A. 75: 2030-2034.

Linser, P., and A. A. Moscona (1981) Carbonic anhydrase C in the neural retina: Transition from generalized to glia-specific cell localization during embryonic development. Proc. Natl. Acad. Sci. U. S. A. 78: 7190-7194.

Mirsky, R., L. M. B. Wendon, P. Black, C. Stolkin, and D. Bray (1978) Tetanus toxin: A cell surface marker for neurons in culture. Brain Res. 148: 251-259.

Nichols, D. H., and J. A. Weston (1977) Melanogenesis in cultures of peripheral nervous tissue. I. The origin and prospective fate of cells giving rise to melanocytes. Dev. Biol. 60: $217-225$.

Nichols, O. H., R. A. Kaplan, and J. A. Weston (1977) Melanogenesis in cultures of peripheral nervous tissue. II. Environmental factors determining the fate of pigment-forming cells. Dev. Biol. 60: 226-237.

Nishi, R., and D. K. Berg (1977) Dissociated ciliary neurons in vitro: Survival and synapse formation. Proc. Natl. Acad. Sci. U. S. A. 74: 5171-5175.

Nishi, R., and D. K. Berg (1979) Survival and development of ciliary ganglion neurons grown alone in cell culture. Nature 277: 232-234.

Patterson, P. H. (1978) Environmental determination of autonomic neurotransmitter functions. Annu. Rev. Neurosci. 1: $1-18$.

Reichardt, L. F., and P. H. Patterson (1977) Neurotransmitter synthesis and uptake by isolated sympathetic neurones in microcultures. Nature 270: 147-151.

Rohrer, H., and Y. A. Barde (1982) Presence and disappearance of nerve growth factor receptors on sensory neurons in culture. Dev. Biol. 89: 309-315.

Rothman, T. P., M. D. Gershon, and H. Holtzer (1978) The relationship of cell division to the acquisition of adrenergic characteristics by developing sympathetic ganglion cell precursors. Dev. Biol. 65: 322-341.

Schachner, M., S. K. Kim, and R. Zehnle (1981) Developmental expression in central and peripheral nervous system of oligodendrocyte cell surface antigens ( 0 antigens) recognized by monoclonal antibodies. Dev. Biol. 83: 328-338.

Sherwin, S. A., A. H. Shishi, and G. J. Todaro (1979) Human melanoma cells have both nerve growth factor and nerve growth factor-specific receptors on their cell surface. Proc. Natl. Acad. Sci. U. S. A. 76: 1288-1292.

Sommer, I., and M. Schachner (1981) Monoclonal antibodies (01 to 04) to oligodendrocyte cell surfaces: An immunocytological study in the central nervous system. Dev. Biol. 83: $311-327$.

Sommer, I., and M. Schachner (1982) Cells that are 04 antigenpositive and 01 antigen-negative differentiate into antigenpositive oligodendrocytes. Neurosci. Lett. 29: 183-188. 
Sutter, A., R. J. Riopelle, R. M. Harris-Warrik, and E. M. Shooter (1979a) Nerve growth factor receptors: Characterization of two distinct classes of binding sites on chick embryo sensory ganglia cells. J. Biol. Chem. 254: 5972-5982.

Sutter, A., R. J. Riopelle, R. M. Harris-Warrik, and E. M. Shooter (1979b) The heterogeneity of nerve growth factor receptors. In Transmembrane Signalling, M. Bitensky, R. J. Collier, D. F. Steiner, and C. F. Fox, eds., pp. 659-667, Alan R. Liss, Inc., New York.

Teillet, A. M., and N. M. Le Douarin (1974) Détermination par la méthode des greffes heterospecifiques d'ebauches neurales de caille sur l'embryon de Poulet, du niveau du névraxe dont dérivent les cellules médullo-surrénaliennes. Arch. Anat. $\mathrm{Mi}$ crosc. Morphol. Exp. 63: 51-62.

Thoenen, H., and Y. A. Barde (1980) Physiology of nerve growth factor. Physiol. Rev. 60: 1284-1335.

Varon, S., M. Manthorpe, and R. Adler (1979) Cholinergic neuronotrophic factors. I. Survival, neurite outgrowth and choline acetyltransferase activity in monolayer cultures from chick embryonic ciliary ganglia. Brain Res. 173: 29-45.

Vogel, Z., A. J. Sytkowski, and M. W. Nirenberg (1972) Ace- tylcholine receptors of muscle grown in vitro. Proc. Natl. Acad. Sci. U. S. A. 69: 3180-3184.

Wakshull, F., M. I. Johnson, and H. Burton (1978) Persistence of an amine uptake system in cultured rat sympathetic neurons which use acetylcholine as their transmitter. J. Cell Biol. 79: 121-131.

Weston, J. A. (1963) A radiographic analysis of the migration and localization of trunk neural crest cells in the chick embryo. Dev. Biol. 6: 279-310.

Weston, J. (1981) The regulation of normal and abnormal neural crest development. Adv. Neurol. 29: 77-94.

Yen, S. -H., and K. L. Fields (1981) Antibodies to neurofilament, glial filament and fibroblast intermediate filament proteins bind to different cell types of the nervous system. J. Cell Biol. 88: 115-126.

Yntema, C. L., and W. S. Hammond (1947) The development of the autonomic nervous system. Biol. Rev. 22: 344-359.

Zimmermann, A., and A. Sutter (1982) Nerve growth factor receptors on non-neuronal cells of dorsal root ganglia. In Neuroreceptors, F. Hucho, ed., pp. 77-87, Walter de Gruyter, Berlin. 